\title{
小動物臨床家のための臨床検査機器とその応用 (VII)
}

寄生虫検査の機 器

茅 根 士 郎*

小動物に寄生する原虫, 蠕虫（線虫, 条虫, 吸虫）の 多くは消化器, 胆管, 呼吸器系に寄生するので, 虫卵, 囊子（シスト），オーシストまたは虫体，片節が䔬便を 通じて宿主体外に排出される. したがって，寄生虫の診 断法としては粪便検査（虫卵検査）が主要な検査法とな る. しかし, 循環器系に寄生する犬系状虫, 血液寄生原 虫（バベシア）などは血液を検査しなければならない し, 泌尿器系に寄生する腎虫, 毛細線虫などは尿検査に よってはじめて診断が可能である. さらに, 犬・猫など の眼にみられる東洋眼虫の検査は瞬膜に寄生する成熟虫 を肉眼的に検出する必要がある. しかし, 寄生している 虫体が幼若虫の場合, あるい㨳生虫体数がきわめて少 ない場合, 雄虫のみの単性寄生の場合は上述の検査法に よっても虫卵は検出されない。したがって，このよらな 場合には免疫学的検查法が寄生虫診断の一助となる。 、 っぽう, 外部寄生虫（小形ダ二類）は宿主の体表, 皮下 に寄生するため, 患部病巣およびその周辺部を搔き取っ て顕微鏡下で調べなければならない，このように，小動 物の寄生虫診断と一ロにいってもその検査法は多岐にわ たって括り，どのような検査法を実施した場合，いかな る寄生虫が検出されるかをある程度想定できる寄生虫学 的知識が要求される. また, 寄生虫によっては風土病的 にある地方に限定されて発生（犬のバベシア，肺吸虫， 東洋眼虫）するので, 検査にあたってはとの点を留意す る必要がある.

寄生虫領域では診断のための大きな器機はあまり必要 としない.どんな検査機器を用いて検出したとしても, 検出された虫卵・子虫を同定することができなければ診 断の役に立たない以上, 機器よりる検查の習熟, 検出さ れた寄生虫を同定する技術・知識が優先することは当然 である. 以下, 小動物領域において寄生虫を診断するに あたって主要な検査法の術式, 機器の取り扱い方, また 最近新たに導入された検査器具の術式について解説して みたい.

\section{1. 寄生虫診断における糞便検査}

\section{1) 糞 便材 料 の採取}

* 麻布大学獣医学部 (神奈川県相模原市㴊野辺1-1771)
可検材料は新鮮な䔬便を使用しなければならない. 排 䔬後時間の経過した検体を使用すると, 消化管に寄生す る原虫の栄養型は検出できない。また，犬鉤虫，猫鈎虫 の虫卵は発育が早く，短時間で含子虫卵となり，次いで 子虫が餒化するため, 含子虫卵や子虫として新鮮䔬便中 に排泄される猫䔬線虫 (Strongyloides planiceps) や頖線虫 (Strongyloides stercoralis) との鑑別が不可能になる.したが って，ただちに検査できない場合は糞便を密閉容器に入 れて冷蔵庫 $\left(4^{\circ} \mathrm{C}\right)$ に保存し, 虫卵の発育を抑制するか, 5〜10\% ホルマリン液を注加し, 虫卵の発育を阻止する 必要がある.

\section{2) 䝴便の肉眼的検 查}

粪便の肉眼的検査は幼犬での犬回虫や条虫感染などの 場合, 自然排泄虫体や片節（犬条虫，猫条虫，豆状条 虫，胞状条虫）の確認は診断に有効である．とくに，犬 条虫（瓜実条虫）では䔬便中の離脱片節が周囲に卵囊を 排出するが，卵襄は比重が大きくしかも䔬便中に均等に 分散していないため，浮遊法などによる虫卵検査で検出 することは難しい.

\section{3）䔬 便の顕 微 鏡 検 査}

虫卵, 子虫, 原虫 (栄養型, 囊子, オーシスト) が検 查の対象となる. 直接塗抹法と集虫法がある. 集虫法は 浮遊法と沈殿法にわけられる.

\section{(1) 直接塗抹法}

\section{[術式]}

(1) スライドグラスの中央部に蒸留水 (水道水でも可) を $1 \sim 2$ 滴落とす.

(2) 爪楊枝の先に付く程度の量（2３ mg）の可検便 を取る。

(3) スライドグラス上の水と䔬便を爪楊枝の先でよく 混和する. 大きな夾雑物がある場合はこれを除去した 後, カバーグラス $(18 \times 18 \mathrm{~mm})$ をかぶせ, 倍率 100 400 倍で全視野を鏡検する.

通常は同様な標本を 3 枚作り観察する必要がある. 犬 回虫, 犬小回虫, マンソン裂頭条虫卵は産卵数が多いた め比較的容易に検出できる. また, 犬鈎虫, 犬鞭虫が多 数寄生している場合にる検出できる.なお, 腸ジアルジ ア，腸トリコモナスの検査を目的とする場合には糞便は 水のかわりに生理食塩液で希釈する方がよい。 
（2）ギムザ染色法（腸管内原虫検查法）：ジアルジア， トリコモナスなどの腸管内寄生原虫の検査に使用される 染色法である.

〔術式〕

(1) 少量の可検便を爪楊枝の先に取り，スライドグラ スに薄く塗抹し風乾する.

(2) バットの中にガラス棒を 2 本平行に並べ，その上 に塗抹標本を置く. 次に純アルコールをスライドグラス に盛り上げ， $2 \sim 3$ 分間固定する.

(3) アルコールを捨て, ギムザ染色液〔ギムザ原液 (Merk 製) 1 3 ml, 蒸留水 $100 \mathrm{~m} l$ を加宇たもの〕を かけ，20〜60 分間染色する.

(4) 染色液を捨て，塗抹面を下にして水道水で余分の 染色液を洗ったのち, 乾燥, 鏡検する。

（3）浮遊法：集虫法の1つで, 虫卵(オーシスト, 翼子) よりも比重の重い液を用いて, 虫卵を液の表面に浮上さ せて集卵させる方法である。浮遊液の比重は 1.18 1.250 が適当で，それ以上高い比重液を使用すると虫卵 以外の夾雑物が浮上し，虫卵の観察に支障をきたす。た だし，比重の重い胃虫 (Physaloptera praeputialis) や血色 食道虫 (Spirocercalupi) の虫卵を浮遊法で検出する場合 には, 飽和硝酸ナトリウム液（比重 1.390）を用いるこ とがある。

主要な浮遊液の作り方は次のようである。

(1) 飽和塩化ナトリウム液（比重 $1.20 ）:$ 水 $1 l$ に食 塩 $360 \mathrm{~g}$ を溶かす.

(2) 硫酸亜鉛溶液（比重 $1.18 ）:$ 水 $1 l$ 飞硫酸亜 鉛 $331.4 \mathrm{~g}$ を溶解.

(3) 塩化カルシウム溶液（比重 1.250）: 水 $1 l$ 飞塩 化カルシウム $440 \mathrm{~g}$ を溶解.

(4) 庶糖液（比重 1.20 ): 水 $115 \mathrm{ml}$ に砂糖 $100 \mathrm{~g}$ を 溶解. アルコール発酵を防止するため石炭酸を 0.5 $1.0 \%$ の割合で加える.

\section{《飽和食塩液浮遊法》}

\section{〔術式]}

i 可検便 $0.5 \sim 1.0$ g を小形ビーカー（市販の紙コ ップでも可) に取り, 約 10 倍量の飽和食塩液（比重 1.20）を加えてガラス棒で十分に攪拌し，均一な粪汁を 作る.

ii ガーゼ1枚をのせたロートないし80〜100メッシ 二の金属性金鋼（市販の茶こしでも可）を使って䔬汁を 別のビーカーに濾過する.

iii 濾液を試験管立てに置いた小試験 管（105×15 $\mathrm{mm}$ ) に入れ, 液面が盛り上がるまで筫汁を徐々に注加 する。

iv $10 \sim 20$ 分間静置後，カバーグラスを液面に接触 させ，これをスライドグラスの上に置き鏡検する。

時間に余裕があれば可検便を水で溶き，遠心沈殿
（2,000 rpm 2 分間） 乙，上清を拾て，沈殿物を翼拌し ながら飽和食塩液を液面が盛り上がるまで加光, 上記の 操作法の iv に準じて虫卵を検出寸ると，夾雑物が少な く観察しやすい.

（4）遠心沈殿法：比重の高い吸虫卵，条虫卵などの検 査括よび原虫の囊子の検出が可能である. 遠心沈殿法に は MGL 法（ホルマリン・エーテル法）, AMS III法, MIFC 法などがある. 最近, アメリカで MGL 法を応 用した虫卵検查器具, FPC キット (Fecal parasite concentrator）が開発され，小動物・実験動物の翼便検 査器具として普及して括り, 日本でも輸入・発売されて いる (発売元 : Evergreen 社 輸入元: 利康商事). こ の虫卵検査器具は 2 本の試験管 (ポリプロピレン製) と, この 2 本の試験管を接続する部品（この接続部品の中に 滤過器が組み込まれている) からなり，2 本の試験管の 中で沈殿法の全ての操作ができるような仕組みになって いる. 乙たがって, 従来の沈殿法にくらべて操作が簡単 で，密閉された試験管内で糞便を処理するので清潔であ り，悪臭もなく，寄生虫污染の防止にもなる. 以下，そ の操作法について簡単に説明する.

《FPC 法 (Fecal Parasite Concentrator 法) (写 真 1$)\rangle$

i $15 \mathrm{ml}$ 容量の平底試験管に $10 \%$ ホルマリン液 9 $\mathrm{m} l$ を入れる.

ii 付属のスプーンを使って新鮮な粪便から2杯分採 取し試験管に入れ，スプーンで覺拌・溶解する. 次に， 蓋をして強く振盪し均一な粪汁とする. さらに, この翼 汁の中に 20\% triton X100（この界面活性剤は觵便と虫 卵を分離させる役目をもち, したがって虫卵の検出率が 高くなる、沈殿法の中では AMS III法がこの薬凪を用い ている）を3 滴加え， 10～20 分間放置する.

iii 平底試験管の蓋を除去し, 濾過器を接続する. 次 に濾過器の上端に尖底試験管を取り付け, 粪汁の入った 平底試験管を反転して, 数分間静置すると䔬汁は濾過さ

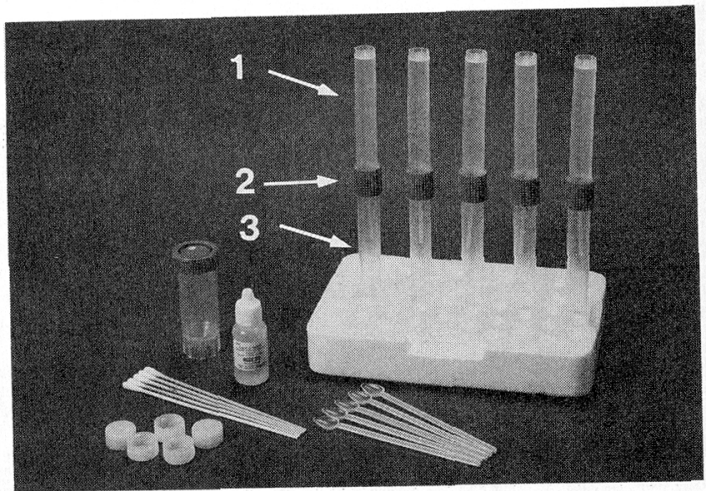

1: 平底試験管 2 : 濾過器 3 : 尖底試験管 写真 1 FPC 法 (沈殿法) 検査器具 
れて尖底試験管に移る。

iv 平底試験管と濾過器を取り除き, 粪汁濾過液に $3 \mathrm{~m} l$ のエチルアセテート(エチルェーテルでも可。ただ し，エチルアセテートに比べて可然性が高いので，取り 扱いに注意が必要）を加光，蓋をして 20〜30 秒間上下 に強く振遑する.

v 2,000 rpm，2 分間遠心沈殿する.

vi 尖底試験管の蓋をはずし，付属品の綿棒の反対側 の先端を使ってェーテル層, 糞便層, ホルマリン層の 3 層を管壁に沿って剝離する.この 3 層を捨てたのち, 綿 棒で管壁をきれいに拭き取る。

vii 沈椬に $2 \sim 3$ 滴の水道水または生理食塩液を加宇 て十分に混和寸る．次に毛細管ピペットで吸引し，スラ イドグラスに沈椬を滴下し，カバーグラスをかけて鏡検 する。

FPC 法は虫卵以外にも原虫の囊子，オーシストの検 出が可能である. また，ホルマリン液の代りに塩類溶 液, 庶糖液を使用寸れば浮遊法としても使光る利点があ る。

\section{2. 寄生虫診断における血液検査}

小動物 (犬，猫）領域で循環器系に寄生するものとし ては犬のバベシア (Babesia gibsoni, B. canis), 犬糸状虫 などがある。

\section{1) 犬のピロプラズマ検査}

新鮮血液をスライドグラスに薄層塗抹する．術式，染 色法は䔬便内原虫検査に準ずる。

\section{2）犬糸状虫のミクロフィラリア検査}

血液中のミクロフィラリア検査には值接塗抹法, 厚層 塗抹法，集虫法などがある，最近，集虫法のキットが数 社から市販されている (写真 2,3 ). いずれもフィルタ 一集虫法である。

（1）ミクロフィラリアフィルター集虫法（ $\mathrm{mf}$ キット： 共立商事) (写真 2)

[術式]

(1) $0.5 \%$ の炭酸ナトリウムの溶解液 $9 \mathrm{~m} l$ を遠心管 に入れ，血液 $1 \mathrm{~m} l$ を加光混和寸る。

(2) 室温に 20３0 分間放置して完全に溶血させる.

(3) 全液を $10 \mathrm{ml}$ の注射器に移しミミリポアーフィル ター（孔径 $8 \mu \mathrm{m}$, 直径 $25 \mathrm{~mm}$ ) を入れたホルダーを注 射器に接続する.

(4) 注射器のポンプをゆっくり押して溶血液を濾過す る.

(5) 注射器に水 $10 \mathrm{ml}$ を取り, 再度濾過する.

(6) 注射器のポンプを外して空気を入れ，ポンプを押 して空気を送り残水を排出する.

(7) ピソセットを使ってフィルターをスライドグラス 上に移し，染色液 $(0.1 \%$ ×チレンブルー液)を $3 \sim 4$ 滴
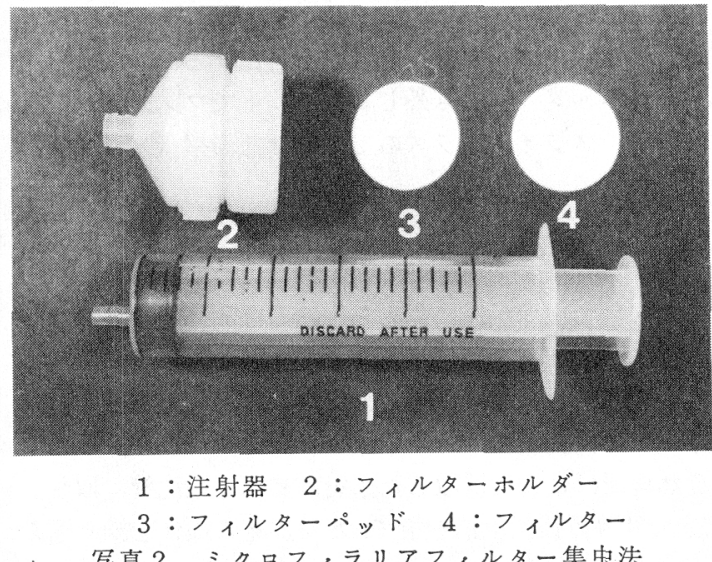

写真 2 ミロロフィラリアフィルター集蜐

落とし，カバーグラス $(24 \times 32 \mathrm{~mm})$ をかけて低倍率 （×50〜100）で鏡検する.染色されたミクロフィラリア が観察される。

（2）ミクロフィラリア透明フィルター集虫法（ $\mu$-filax キット 発売元; ジャパン・メンブレン, 製造元; 城北 医科機器製作所）（写真 3 ）：ミクロフィラリアフィルタ 一集虫法では血液を溶血させ，ミクロフィラリアを染色 して観察するのに対して，この透明フィルター集虫法で は血液をそのままの状態で透明な特殊フィルターを使っ て濾過し，ミクロフィラリアを染色せず，生きた状態で 観察するなどの点がフィルター集虫法（mf キット）と 異なる。

〔術式〕

(1) 採血用注射筒にあらかじめ EDTA 液 $0.1 \mathrm{~m} l$ を 取り，可検犬から $1 \mathrm{ml}$ 採血する.

(2) $25 \mathrm{ml}$ 注射筒に採血した血液を入れ， $\mu$-filax溶液 を $1 \mathrm{~m} l$ 加壳て軽く混和寸る。

(3)さらに, PBS 溶液を加えてよく混和する.

(4) $25 \mathrm{~m} l$ 注射筒をホルダーに接続して, 注射器のポ ンプを徐々に加压して血液を濾過する。

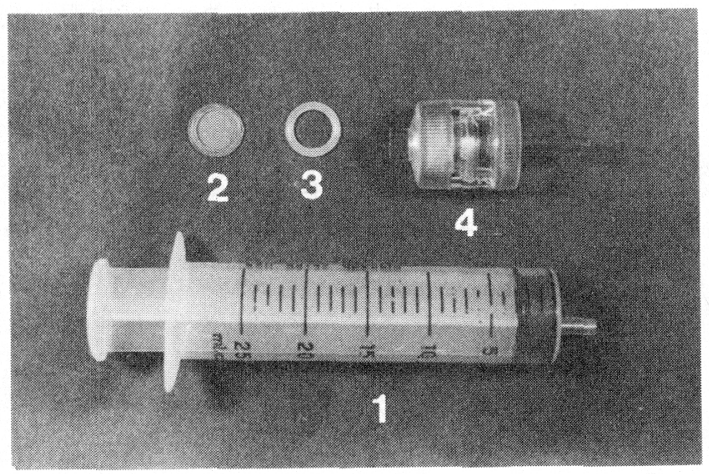

1 : 注射器 2 : 透明フィルター $3:$ パッキング $4:$ :ルダー

写真 3 ミクロフィラリア透明フィルター集虫法 
技術

(5) 注射器のポンプを外し空気を入れ，ポンプを押し てホルダー内に空気を送り残血を排出する.

(6) ホルダーを取り外しピンセットでフィルターを取 り出し，スライドグラスの上にのせ低倍率 $(\times 50 \sim 100)$ で鏡検する.

\section{3. 尿 の 寄 生 虫 検 査}

犬・猫で虫卵が尿に認められるのは腎虫 (Dioctophyma renale) と毛細線虫 (Capillaria felis-cati) である. 腎虫は 犬・猫などの腎臓に，毛細線虫は猫の膀胱に寄生する。 尿の虫卵検査に際しては尿道カテーテルにより，または 自然排尿によって採取した尿をスピッツ遠沈管に取り， 10 分間静置後, 上清を拾て, 水を加える操作を繰り返え す. 次に沈椬をスライドグラスに取り，カバーグラスを かけて鏡検する. 虫卵を保存する場合は沈渣に 10\% ホ ルマリン液を加えるとよい，腎虫卵は棈円形（60～80× 40〜45 $\mu \mathrm{m})$ で色は黄褐卵，卵殼の表面は多くの凹みを 有し，独特な形をしている．また，膀胱の毛細線虫卵は 犬鞭虫卵に類似し，虫卵の両端に栓状構造を有するが， 犬鞭虫卵に比べてやや小さく，65～67×26～30 $\mu \mathrm{m}$ で表 面に点状の小さな孔状構造を有する点で犬鞭虫卵と区別 でさる。

\section{4. 皮膚の寄生虫検查}

小動物の体表および皮膚組織内にはダニ類，昆虫類が 寄生する.ダ二類には皮膚面で吸血する中形ないし大形 のマダ二類，皮膚面で皮垢を食べる小形のッメダ二, 耳 道に寄生する耳疥癬（ミミヒゼンダ二）と皮膚組織内に 寄生する奖鷹虫 (ヒゼンダ二), 毛包虫（二キビダ二） がある.

1）ダニ類, 昆虫（ノミ, シラミ, ハジラミ）の採取・ 保存法

マダニ類は宿主の耳・眼の周辺, 胸部などの好寄生部 位に多くみられる. マダ二類は体表から採取する際に手 荒くすると口器が宿主の皮膚内に残るので慎重に取り扱 わなければならない。 また，シラミは口器を皮膚の中に 挿入して寄生し，ハジラミは毛の間を歩き回わっている ので，いずれる眼科用ピンセットを用いて採集する. 採 取したダ二類, 昆虫類は標本瓶に入れ，70\%アルコール またはグリセリン・アルコール $(70 \%$ アルコールに $1 / 10$ 量の局方グリセリンを加えたもの）を入れて保存する. 必要に応じて取り出し, 封入標本を作製して種を同定す る.

2）小形ダニ類, 昆虫（ノミ，シラミ，ハジラミ）の 簡単な封入標本作製法

[ゲーター液処方]
(1) アラビアゴム $8 \mathrm{~g}$
(2) 抱水クロラール $30 \mathrm{~g}$
(3) 蒸留水
$10 \mathrm{~m} l$
(4) 水酢酸

講座

上記の順序に従って試薬を乳鉢の中に入れ，よく砕い て溶かし，遠沈（2,000 rpm，5 分間）ないし数日間放 置し，上清を取って使用する.

[術 式]

(1) スライドグラスにゲーター液を 1 滴取り，小形ダ 二類打よび昆虫類を入れ，カバーグラスをかける.

(2) アルコールランプないしガスバーナーの弱火で遠 くから気泡ができるまで暖める（標本は固定・透化され る).

(3) カバーグラスの周囲をラッカーないしマニキュア で封じると，液の蒸発を防ぎ長期間保存できる。ただ し，永久標本を作製するためには，バルサム封入法，石 炭酸バルサム法がよい。

\section{3）小形ダ二類の皮膚検査}

〔術式〕

(1) スライドグラスに軽潤滑油（ミシン油）を 1 滴た らす.

(2) メスに油をつけ，そのメスで患部の病巣部ないし 周辺部の皮䖉を搔き取る.

(3) メスに付着した搔爬物をスライドグラスの油の中 飞移生。

(4) カバーグラスをかけて, 低倍率 $(\times 100)$ で全視 野を観察する。

この検查法によって, 犬穿孔疥癄虫（イヌセンコウヒ ゼンダニ; Sarcoptes canis)，猫小穿孔庎䱦虫（ネコショ ウヒゼンダニ; Notoedres cati), 犬毛包虫（イヌニキビダ 二; Demodex canis) などが検出できる. また, 皮膚の撞 爬物が多い場合は $10 \%$ 苛性ソーダまたは苛性カリ液の 中に入れ，宿主の組織を溶解した後，上清を捨て，水を 加光沈渣を調べる.

耳疥痽虫（ミミヒゼンダニ）は犬・猫の外耳道に寄生 するため, 検査は耳鏡 (otoscope) でまず寄生の有無を観 察する. 確認できないときは綿棒を使って耳垢を採取し て調べる. 検查に際して耳垢を黒紙の上飞置き，ルーペ でダニがいるかどらかを検查する，種を同定する必要が ある場合には解剖針の先端にダニを付着させ, スライド グラスの油の中に移し，カバーグラスをかけ鏡検する. 保存する場合にはゲーター液を使って封入標本を作製し 鏡検する.

\section{5. 寄生虫の免疫学的診断法}

雄虫の単性寄生, 幼虫の寄生, 産畉数のきわめて少な い寄生虫の少数寄生では䔬便中に蝴が排泄されない か, たと光排出されても検出することは困難であり，こ のような場合には免疫学的診断法が用いられる. 家畜臨 床関係の寄生虫領域に㧤いて実用化されているのは肝蛭 に対する皮内反応，トキソプラズマに対する色素試験 (Dye test)，凝集反応だけである. 色素試験は従来よりト 
キソプラズマの基本的な免疫診断法として使用されてい るが，操作が煩雑であり，生きている虫体を用いるので 危険を伴い，その使用は特定の試験研究機関に限られ る.トキソプラズマの凝集反応には間接赤血球凝集反応 (THA)，間接ラテックス凝集反応(LA) などがあり，

LA のキットはトキソプラズマーMT として栄研から市 販されている.この診断液は感度, 特異性, 簡易性の点 から色素試験に代るものとして猫のトキソプラズマの抗 体調査の際に使用されている. LA の術式についてい成 書ないし市販のトキソプラズマーMTキットの説明書を 参照されたい。

\section{6. 虫卵（子虫）培養法}

犬・猫の寄生虫はそんなに多くはないので，熟知すれ ば虫卵検査によって種を同定でさるものが多い。しかし 最近, 犬・猫の䔬便検査によってしばしば検出される猫 粪線虫 (Strongyloides planiceps) はとの虫卵が含子虫卵で ある点を除いては鉤虫卵に酷似しており，両者の鑑別は さずかしい。また，犬にみられる粪線虫の1種 Strongyloides stercoralis は贏便中に第 1 期子虫として排泄され る.したがって，これら䔬線虫は最終的には培養によっ て第 3 期子虫（感染子虫）にして種を同定する必要があ る. 小動物の糞便材料を使った虫卵（子虫）培養には濾 紙培養法が適している.

《濾紙培養法 (写真 4$) 》$

[術式]

(1)縦に折目をつけた短冊形の濾紙（170 × $20 \mathrm{~mm}$, あらかじめ中央に折目をつけて握く）の内側に, 下方 5 $\mathrm{cm}$ を残して糞便 $0.5 \mathrm{~g}$ を $2 \mathrm{~cm}$ 幅で $4 \mathrm{~cm}$ 位の長さ に薄く塗布する.

(2) 中試験管 $(160 \times 16 \mathrm{~mm})$ に水道水 $4 \mathrm{ml}$ を入れ, 濾紙を投入する（その際，粪便の塗抹部が水中に没しな いように注意する。培養液が筫便で污れると稃化した子 虫が死隇する).

(3) 試験管の管口を約 $3 \mathrm{~cm}$ 平方に切ったビニール 2 枚で覆い，輪ゴムで密閉する.

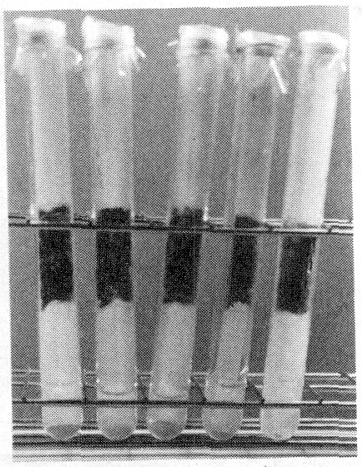

写真 4 濾 紙 培 養 法
(4) $25 \sim 27^{\circ} \mathrm{C}$ の卯学卵器 (夏期の場合は室温でも可) で 7 日間培養する.

(5) ピソセットで濾紙を除去し，管底を毛細管ピペッ トで吸引して，スライドグラスに 1 滴落とし， ヨード液 をかけて子虫を殺し，その構造を観察する。

犬鉤虫, 猫銁虫の感染子虫以糞線虫の感染子虫に比へ て太く，食道の長さが体長の $1 / 4$ 以下であるのに詨して 䔬線虫の感染子虫は食道が長く, 体長の約 $1 / 2$ に達す る.また，糞線虫の感染子虫は尾端が逆 $V$ 字状の切り込 みがある点で銁虫の感染子虫とは容易に区別できる。

\section{7. 虫 卵（オーシスト）計 数 法}

糞便 $1 \mathrm{~g}$ 中に含まれる虫卵数 (EPG：Eggs per gram) またはコクシジウム(原虫)のオーシスト (OPG: Oocyst per gram) を計数し, 寄生虫体数の推定, 駆虫効果の判 定を行う. 計数法には McMaster 改良法 (EPG 計算盤 法)，Stoll 法，クローム硫酸法などがある.

《McMaster 改良法 (EPG 計算盤法)（写真 5)》

浮遊法を応用した方法である。試薬に塩類溶液や庶糖 液を使用する。したがって，オーシストや線虫卵は計数 できるが，比重の高い吸虫卵，条虫卵には不適であり， これら虫卵の計数には Stoll 法が用いられる。

〔術式]

(1) 計量した䔬便 $2 \mathrm{~g}$ を $100 \mathrm{ml}$ のビーカーに取り, 塩類溶液（飽和食塩液） $58 \mathrm{ml}$ を入れ, 十分に攪拌・溶 解して均一な䔬汁を作る。

(2) 糞汁を 80 100メッシュの金属性金網（市販の茶 こし器でも可) を用いて別のビーカーに濾過する.

(3) 濾過した糞汁を十分に攪拌しながら毛細管ピペッ トで吸い上げ，McMaster 計算盤（富士平工業製）の両 室（各室 $0.15 \mathrm{ml}$ ) に満たし, 数分間静置する. 次に顕 微鏡で一方の室の画線に焦点を合わせ, 左右の横線の区 画内に浮上した虫卵ないしオーシスト数を種類別に計算 する。

全量 $60 \mathrm{ml}$ の糞汁には䔬便 $2 \mathrm{~g}$ を含むので, $1 \mathrm{~g}$ の䔬 便が含まれる穓汁量は $30 \mathrm{ml}$, そのらち計数した䔬汁量 は $0.3 \mathrm{ml}$ である. したがって, 粪便 $1 \mathrm{~g}$ 中の虫卵数 (オーシスト数) は,

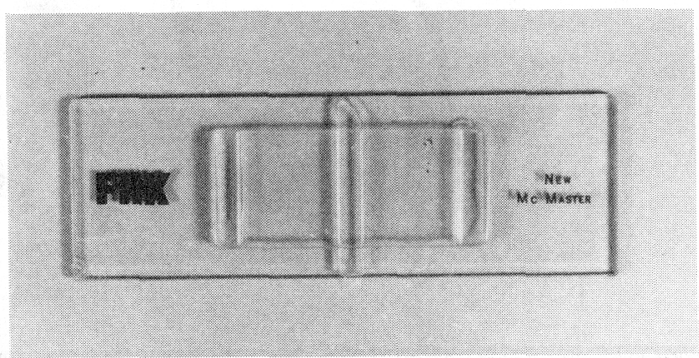

写真 5 McMaster 計算盤 


$$
\mathrm{EPG}(\mathrm{OPG})=x \times \frac{60}{0.3} \times \frac{1}{2}=x \times 100
$$

となり，種類別に計数した虫卵 (オーシスト) 数 $(x)$

に 100 倍した值が䔬便 $1 \mathrm{~g}$ 中に含まれるその虫卵（オー シスト）の数になる.

注）McMaster 計算盤は, 煮沸隇菌するとスライドグ ラスと各室の接着部分が剝がれやすくなるので，McMaster 計算盤を熱湯中に瞬間（1 分以内）浸して虫卵,
オーシストを処置する．McMaster 計算盤の接着部が剝 がれた場合は接着剤（アロンフルファ）などで補修する とよい，また，犬回虫卵など蛋白膜をもつ虫卵は浮上し た際に計算盤の各室の区画線上に付着し，水洗した程度 では虫卵は除去できず，次回の操作に支障をきたす，乙 たがって，使用毎に McMaster 計算盤の各室にガーぜ を通し，虫卵を除去しなければならない。

要 指

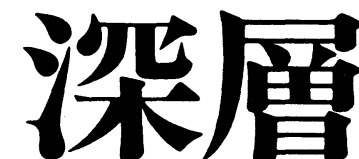
咅 阝\% 透 10倍以上に 膨張拡散、吸着します。

発泡乳化性乳房内投与剂

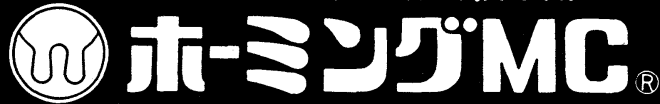
乳頭消毒用清浄綿付 FMC

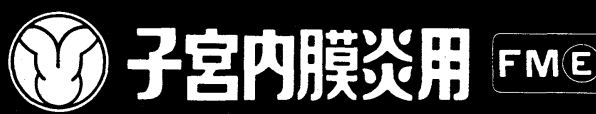

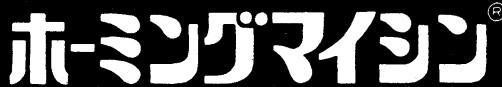

FOAMING MYCIN FOR LIVE STOCKUSE

埼玉祡川口市元郷 $4-1-8$

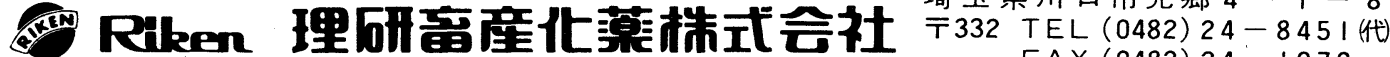
FAX (0482) $24-1079$

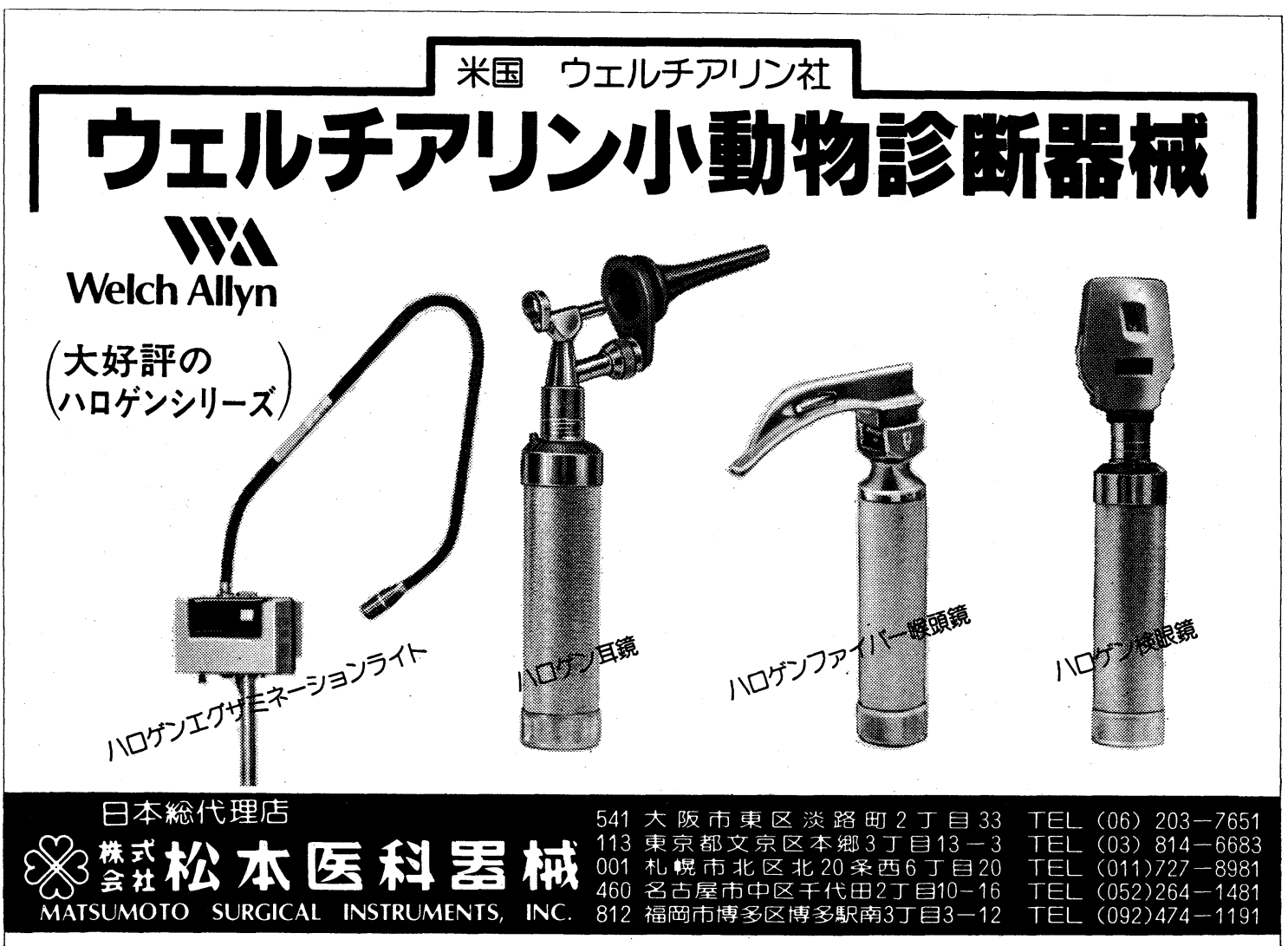

